\title{
Zebrafish as a Model System for Investigating the Compensatory Regulation of Ionic Balance during Metabolic Acidosis
}

\author{
Lletta Lewis and Raymond W. M. Kwong * \\ Department of Biology, York University, Toronto, ON M3J 1P3, Canada; lewis1@my.yorku.ca \\ * Correspondence: rwmkwong@yorku.ca; Tel.: +1-416-736-2100 (ext. 33718)
}

Received: 12 March 2018; Accepted: 2 April 2018; Published: 5 April 2018

\begin{abstract}
Zebrafish (Danio rerio) have become an important model for integrative physiological research. Zebrafish inhabit a hypo-osmotic environment; to maintain ionic and acid-base homeostasis, they must actively take up ions and secrete acid to the water. The gills in the adult and the skin at larval stage are the primary sites of ionic regulation in zebrafish. The uptake of ions in zebrafish is mediated by specific ion transporting cells termed ionocytes. Similarly, in mammals, ion reabsorption and acid excretion occur in specific cell types in the terminal region of the renal tubules (distal convoluted tubule and collecting duct). Previous studies have suggested that functional regulation of several ion transporters/channels in the zebrafish ionocytes resembles that in the mammalian renal cells. Additionally, several mechanisms involved in regulating the epithelial ion transport during metabolic acidosis are found to be similar between zebrafish and mammals. In this article, we systemically review the similarities and differences in ionic regulation between zebrafish and mammals during metabolic acidosis. We summarize the available information on the regulation of epithelial ion transporters during acidosis, with a focus on epithelial $\mathrm{Na}^{+}, \mathrm{Cl}^{-}$and $\mathrm{Ca}^{2+}$ transporters in zebrafish ionocytes and mammalian renal cells. We also discuss the neuroendocrine responses to acid exposure, and their potential role in ionic compensation. Finally, we identify several knowledge gaps that would benefit from further study.
\end{abstract}

Keywords: acidosis; zebrafish; ionic regulation; ionocytes; kidney

\section{Introduction}

Maintaining ionic and acid-base homeostasis is essential for all organisms. In recent years, the zebrafish (Danio rerio) has become an important model for understanding the mechanisms underlying the regulation of ionic and acid-base balance. Most fish species can only live in a narrow range of $\mathrm{pH}$ near neutrality, primarily owing to the disruption of ionic balance [1]. Zebrafish are highly tolerant to acid exposure (as low as $\mathrm{pH} 4.0$ ), thus they can be useful for investigating the mechanisms underlying acid tolerance. Additionally, the zebrafish model has several advantages over other vertebrate models, including external and rapid development, short generation time, and applicability of many cellular and molecular physiological techniques in vivo (e.g., non-invasive measurements of ion and acid/base movement, whole-animal fluorescence imaging, transgenics, gene knockdown and knockout).

Zebrafish inhabit a hypo-osmotic freshwater (FW) environment. To maintain ionic and acid-base homeostasis, they have to actively absorb ions and secrete acid to the environment. In adult zebrafish, the gills are the predominant site for regulating ion uptake through specific ion-transporting cells termed ionocytes. During larval stages before the gills are fully developed, regulation of ion transport is mediated by ionocytes found in the skin of the yolk sac. The transepithelial transport of major ions, such as $\mathrm{Na}^{+}, \mathrm{Ca}^{2+}$ and $\mathrm{Cl}^{-}$, occurs through three subtypes of ionocytes: $\mathrm{H}^{+}$-ATPase-rich cells 
(HRCs) for $\mathrm{Na}^{+}$uptake, and for $\mathrm{H}^{+}$and ammonia excretion; $\mathrm{Na}^{+}-\mathrm{K}^{+}$-ATPase-rich cells (NaRCs) for $\mathrm{Ca}^{2+}$ uptake; $\mathrm{Na}^{+}-\mathrm{Cl}^{-}$-cotransporter expressing cells (NCCCs) for both $\mathrm{Na}^{+}$and $\mathrm{Cl}^{-}$uptake. In the mammalian kidney, ion reabsorption and acid-base regulation are also mediated by specific cell types (Table 1). In mammals, most transepithelial $\mathrm{H}^{+}$secretion occurs through the apical $\mathrm{Na}^{+} / \mathrm{H}^{+}$exchanger 3 (NHE3) in the proximal tubule. The collecting duct also contributes significantly to $\mathrm{H}^{+}$secretion through $\mathrm{V}$ type $\mathrm{H}^{+}$-ATPase expressed in Type A intercalated cells [2-4]. The expression (Table 1) and functional regulation (Table 2) of ion transporters/channels in the zebrafish ionocytes appear to be markedly similar to that in the mammalian renal cells. Therefore, the zebrafish gill or larval skin may serve as a useful in vivo model for investigating the mechanisms regulating ionic and acid-base balance during acid stress in vertebrates.

The processes in the uptake and acid-base regulation in zebrafish have been comprehensively discussed in several previous reviews [1,5-11]. However, no article has systematically reviewed the similarities and differences in the regulation of epithelial ion transporters between zebrafish and mammals during metabolic acidosis. In this review, we summarize the available information on the regulation of ion transporters in zebrafish ionocytes and mammalian renal cells during acid stress. We discuss the neuroendocrine responses to acid exposure, and their potential role in ionic compensation. Finally, we identify areas that would benefit from future investigations with the zebrafish model.

Table 1. Distribution of major epithelial ion transporters in zebrafish ionocytes and mammalian renal cells.

\begin{tabular}{|c|c|c|c|}
\hline \multirow{2}{*}{ Transporters } & \multicolumn{2}{|c|}{ Gene Name and Cellular Localization of the Protein } & \multirow{2}{*}{$\begin{array}{c}\text { Protein Identity between } \\
\text { Zebrafish and Humans }\end{array}$} \\
\hline & Zebrafish & Mammals & \\
\hline $\mathrm{H}^{+}$-ATPase & $\begin{array}{l}\text { ATP6V1AA. HRCs } \\
\text { (apical) }[12,13]\end{array}$ & $\begin{array}{l}\text { ATP6V1A. Proximal tubular } \\
\text { cells (apical), Type A (apical) } \\
\text { and type B (basolateral) } \\
\text { intercalated cells [14-16] }\end{array}$ & $93 \%$ \\
\hline NHE3 & $\begin{array}{l}\text { NHE3b; SLC9A3.2. } \\
\text { HRCs (apical) }[17,18]\end{array}$ & $\begin{array}{l}\text { NHE3; SLC9A3. Proximal tubular } \\
\text { cells (apical) }[19,20]\end{array}$ & $47 \%$ \\
\hline AE1 & $\begin{array}{l}\text { AE1b; SLC4A1B. HRCs } \\
\text { (basolateral) [21] }\end{array}$ & $\begin{array}{l}\text { AE1; SLC4A1. Type A intercalated } \\
\text { cells (basolateral) [22] }\end{array}$ & $53 \%$ \\
\hline NBCe1 & $\begin{array}{c}\text { NBCe1b; SLC4A4B. } \\
\text { NCCCs } \\
\text { (basolateral) }[21,23]\end{array}$ & $\begin{array}{l}\text { NBCe1-A } \ddagger \text {; SLC4A4. Proximal } \\
\text { tubular cells (basolateral) }[24,25]\end{array}$ & $78 \%$ \\
\hline NCC & $\begin{array}{l}\text { NCC like 2; SLC12A10.2. } \\
\text { NCCCs (apical) }[26,27]\end{array}$ & $\begin{array}{c}\text { NCC; SLC12A3. Distal convoluted } \\
\text { tubular cells (apical) [28-30] }\end{array}$ & $53 \%$ \\
\hline $\mathrm{ECaC}$ & $\begin{array}{l}\text { ECaC; TRPV5. NaRCs } \\
\quad \text { (apical) }[31,32]\end{array}$ & $\begin{array}{c}\text { ECaC; TRPV5. Distal convoluted } \\
\text { tubular cells and principal cells } \\
\text { (apical) }[33-35]\end{array}$ & $48 \%$ \\
\hline $\mathrm{ENaC}$ & $\mathrm{N} / \mathrm{A}^{*}$ & ENaC. Principal cells (apical) $[36,37]$ & $\mathrm{N} / \mathrm{A} *$ \\
\hline
\end{tabular}

$\mathrm{NHE}, \mathrm{Na}^{+} / \mathrm{H}^{+}$exchanger; $\mathrm{AE}$, anion exchanger; $\mathrm{NBCe}$, electrogenic $\mathrm{Na}^{+}-\mathrm{HCO}_{3}{ }^{-}$cotransporter; $\mathrm{NCC}, \mathrm{Na}^{+}-\mathrm{Cl}^{-}$ cotransporter; $\mathrm{ECaC}$, epithelial $\mathrm{Ca}^{2+}$ channel; $\mathrm{ENaC}$, epithelial $\mathrm{Na}^{+}$channel. $\mathrm{HRCs}, \mathrm{H}^{+}$-ATPase-rich cells; $\mathrm{NCCCs}$, $\mathrm{Na}^{+}-\mathrm{Cl}^{-}$cotransporter expressing cells; $\mathrm{NaRCs}, \mathrm{Na}^{+} / \mathrm{K}^{+}$-ATPase-rich cells. TRPV, transient receptor potential cation channel. * The gene encoding for $\mathrm{ENaC}$ has not been identified in teleosts. ${ }^{\ddagger} \mathrm{NBCe} 1-\mathrm{A}$ is a kidney-specific splice variant of NBCe1. 
Table 2. The in vivo effects of acid exposure on the regulation of major epithelial ion transporters in zebrafish ionocytes and mammalian renal cells.

\begin{tabular}{|c|c|c|}
\hline \multirow{2}{*}{ Ion Transporters } & \multicolumn{2}{|c|}{ Expression Levels/Activity } \\
\hline & Zebrafish * & Mammals \\
\hline \multirow{2}{*}{$\mathrm{H}^{+}$-ATPase } & \multirow{2}{*}{$\begin{array}{l}\text { Chronic: } \\
\uparrow \mathrm{H}^{+} \text {-ATPase mRNA expression } \\
\uparrow \mathrm{H}^{+} \text {-ATPase activity } \\
\uparrow \text { HRCs density }[12,38,39]\end{array}$} & $\begin{array}{l}\text { Acute: } \\
\uparrow \mathrm{H}^{+} \text {-ATPase mRNA (rabbit) [40] }\end{array}$ \\
\hline & & $\begin{array}{l}\text { Chronic: } \\
\uparrow \mathrm{H}^{+} \text {-ATPase protein abundance (rabbit) [41] }\end{array}$ \\
\hline NHE3 & $\begin{array}{l}\text { Chronic: } \\
\uparrow n h e 3 b \text { mRNA expression [38] } \\
\uparrow \text { NHE3b activity [42] }\end{array}$ & $\begin{array}{l}\text { Chronic: } \\
\uparrow \text { NHE3 protein abundance (rat) }[43,44] \\
\uparrow \text { NHE activity (rat) [45] }\end{array}$ \\
\hline AE1 & $\begin{array}{l}\text { Chronic: } \\
\uparrow a e 1 b \text { mRNA expression [38] }\end{array}$ & $\begin{array}{l}\text { Chronic } \\
\uparrow \text { AE1-expressing cells } \\
\uparrow \text { AE1 protein abundance (rabbit) [46] }\end{array}$ \\
\hline \multirow[t]{2}{*}{$\mathrm{NCC}$} & $\begin{array}{l}\text { Acute: } \\
\leftrightarrow n c c \text { mRNA expression } \\
\leftrightarrow \text { NCCCs density } \\
\uparrow \text { NCC activity [26] }\end{array}$ & $\begin{array}{l}\text { Acute: } \\
\leftrightarrow \text { NCC protein abundance (rat) [47] }\end{array}$ \\
\hline & $\begin{array}{l}\text { Chronic: } \\
\uparrow n c c \text { mRNA expression } \\
\uparrow \text { NCCCs density [48] }\end{array}$ & $\begin{array}{l}\text { Chronic: } \\
\uparrow \text { NCC protein abundance (rat) [47] }\end{array}$ \\
\hline $\mathrm{ECaC}$ & $\begin{array}{l}\text { Chronic: } \\
\uparrow \text { ecac-expressing cells } \\
\uparrow \text { ECaC activity [49] }\end{array}$ & $\begin{array}{l}\text { Chronic: } \\
\downarrow \text { ecac (TRPV5) mRNA expression } \\
\downarrow \text { ECaC protein abundance (mice) [50] }\end{array}$ \\
\hline
\end{tabular}

$\uparrow$ Increase, $\downarrow$ decrease, $\leftrightarrow$ no change. * Regulation of ion transporters at larval stages ( 0 to 4 days post-fertilization). Acute: $\leq 24$ h of exposure, chronic: $>1$ day of exposure.

\section{Physiological Responses and Compensatory Regulation of Ion Transport during Acidosis}

\subsection{Overview of the Effects of Acid Exposure on Freshwater Fish}

In most FW fish species studied, the primary effects of acid exposure are inhibition of active $\mathrm{Na}^{+}$uptake coupled with stimulation of passive $\mathrm{Na}^{+}$losses (for a review, see [1]). This disruption in $\mathrm{Na}^{+}$regulation by acid exposure may result in a decrease in plasma $\mathrm{Na}^{+}$level, ultimately leading to cardiovascular failure and mortality [51]. The reduced $\mathrm{Na}^{+}$uptake by acid exposure is thought to occur through competitive inhibition with an elevated water $\mathrm{H}^{+}$level [52]. Additionally, $\mathrm{Na}^{+}$uptake in FW fish is predominately linked to $\mathrm{H}^{+}$secretion through the actions of the $\mathrm{Na}^{+} / \mathrm{H}^{+}$exchanger (NHE) and $\mathrm{H}^{+}$-ATPase at the apical membrane [53-56]. Therefore, the elevated level of $\mathrm{H}^{+}$in the environment may reduce the gradient to drive $\mathrm{Na}^{+}$influx. On the other hand, the increased $\mathrm{Na}^{+}$efflux during acid exposure is believed to be associated with the disruption in the integrity of epithelial tight junction, thereby increasing the passive loss of $\mathrm{Na}^{+}$through paracellular route [1]. Zebrafish, however, are able to increase active $\mathrm{Na}^{+}$uptake and reduce paracellular $\mathrm{Na}^{+}$loss following acid exposure. Several recent studies have demonstrated that zebrafish can also increase their capacity for $\mathrm{Ca}^{2+}$ and $\mathrm{Cl}^{-}$uptake after acid exposure (discussed below). These compensatory responses are associated with an activation of a complex network of regulatory mechanisms, including modulation of the expression of ion transporters, stimulation of hormone production and thereby activation of its downstream signaling pathways, changes in the abundance of epithelial tight junction proteins, remodeling of ionocyte differentiation and proliferation, and post-translational regulation of ion transporters. A simplified model of the effects of acid exposure on zebrafish ionocytes is illustrated in Figure 1. 
Acidic water

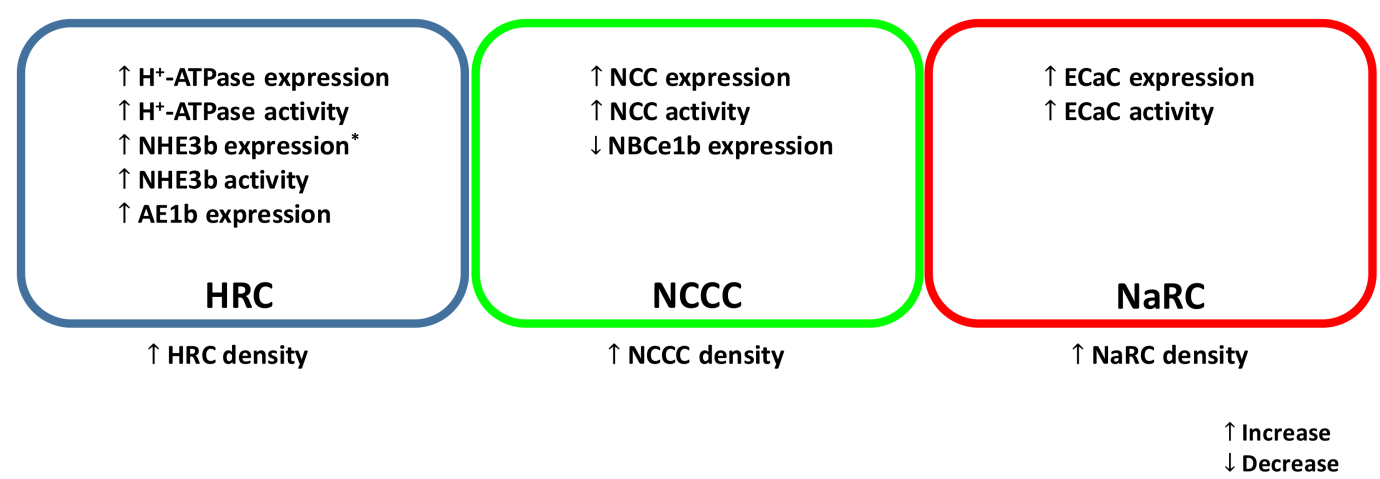

Figure 1. A simplified model illustrating the effects of acute and/or chronic acid exposure on zebrafish ionocytes. $\mathrm{NHE}, \mathrm{Na}^{+} / \mathrm{H}^{+}$exchanger; $\mathrm{AE}$, anion exchanger; $\mathrm{NCC}, \mathrm{Na}^{+}-\mathrm{Cl}^{-}$cotransporter; $\mathrm{NBCe}$, electrogenic $\mathrm{Na}^{+}-\mathrm{HCO}_{3}{ }^{-}$cotransporter; $\mathrm{ECaC}$, epithelial $\mathrm{Ca}^{2+}$ channel.HRC, $\mathrm{H}^{+}$-ATPase rich cell (blue); NCCC, NCC expressing cell (green); $\mathrm{NaRC}, \mathrm{Na}^{+} / \mathrm{K}^{+}$-ATPase rich cell (red). * In acidic water, mRNA encoding NHE3b is increased in larvae but decreased in adult gills.

\subsection{Functional Regulation of Ion Transporters and Their Involvement in Ionic Compensation during Acidosis}

\subsection{1. $\mathrm{Na}^{+} / \mathrm{H}^{+}$Exchanger (NHE)}

In mammals, NHE3 (SLC9A3) is the major transporter regulating $\mathrm{Na}^{+}$reabsorption in the proximal tubules of the kidney [57]. In the zebrafish gills/skin, NHE3 (i.e., NHE3b), which is specifically expressed in the apical membrane of HRCs, is also thought to be the predominant transporter for regulating $\mathrm{Na}^{+}$uptake $[17,42,58,59]$. In the mammalian kidney, metabolic acidosis was reported to increase the abundance of NHE3 and its activity in the transport of $\mathrm{Na}^{+}$[43]. In larval zebrafish, mRNA expression of $n h e 3 b$ was found to increase following acid exposure [38]. However, its expression was decreased in the gills of adult zebrafish exposed to acidic water [17,48]. In acidic environments, elevated level of $\mathrm{H}^{+}$in the water is expected to significantly impair $\mathrm{Na}^{+}$uptake via NHE. Interestingly, NHE3b appears to play a role in increasing $\mathrm{Na}^{+}$uptake after acid exposure. It has been suggested that NHE3b-mediated $\mathrm{Na}^{+}$uptake in acidic water is overcome through its interaction with the ammonia transporter Rhcg1 [42]. Diffusion of $\mathrm{NH}_{3}$ through Rhcg1 creates a microenvironment where $\mathrm{H}^{+}$level is lowered by its combination with $\mathrm{NH}_{3}$ to form $\mathrm{NH}_{4}{ }^{+}$. The resultant $\mathrm{H}^{+}$gradient is believed to drive $\mathrm{Na}^{+}$uptake via electroneutral NHE3b. However, recent findings have suggested that in acidic environments, the relative role of NHE3b is reduced and NCC may become the predominant pathway for the absorption of $\mathrm{Na}^{+}$(discussed below).

\subsection{2. $\mathrm{Na}^{+}-\mathrm{Cl}^{-}$Cotransporter (NCC)}

In the distal convoluted tubules of the mammalian kidney, NCC (SLC12A3) is responsible for fine-tuning the reabsorption of filtered $\mathrm{Na}^{+}(5 \%-7 \%)$ [60]. Several studies have investigated the effects of metabolic acidosis on the abundance and function of NCC. However, the findings are currently inconclusive. Following 7 days of metabolic acidosis, it was shown that the expression of NCC, as well as its activity in $\mathrm{Na}^{+}$transport, were decreased in the rat kidney [61,62]. It was also demonstrated that the expression of NCC was increased significantly after 5 days of metabolic acidosis in both rat and mice kidney $[47,63]$. Clearly, further study is required to resolve this inconsistency regarding NCC expression during metabolic acidosis.

In zebrafish, NCC was found to be involved in the compensatory regulation of $\mathrm{Na}^{+}$uptake following acid exposure [26,48]. In zebrafish, NCC (SLC12A10.2; an NCC-like member distinct from the mammalian orthologous of SLC12A3) is expressed in a specific subtype of ionocyte, the NCCCs [27]. Under normal condition, NHE3b plays a more critical role in $\mathrm{Na}^{+}$regulation. However, recent 
studies have demonstrated that NCC could become important under physiological stressors, such as acidosis [26,48] or during periods of increased paracellular ion losses [64]. After acid exposure, the number of NCCCs in larval zebrafish skin as well as in the adult gills was markedly increased [48]. Whole body $\mathrm{Na}^{+}$levels in NCC-deficient fish was also found to be lower than that in control fish following acid exposure [48]. Additionally, it was demonstrated that NCC was involved in the rapid regulation of both $\mathrm{Na}^{+}$and $\mathrm{Cl}^{-}$uptake after acute acidosis [26]. These responses appeared to compensate for the reduced $\mathrm{Na}^{+}$and $\mathrm{Cl}^{-}$uptake during acute acid exposure. Interestingly, this rapid compensation of $\mathrm{Na}^{+}$and $\mathrm{Cl}^{-}$uptake was found to be solely mediated by NCCCs, but not HRCs [26]. How NCC is acutely activated by acid exposure has remained unclear, but it has been proposed to occur via post-translational modification (e.g., phosphorylation) and/or by membrane trafficking [26]. A recent mammalian study has shown that post-translational activation of NCC is associated with the WNK4-SPAK signalling pathway [63]. Whether a similar mechanism also occurs in zebrafish NCC awaits further investigation.

\subsubsection{Anion Exchanger (AE)}

In mammals experiencing metabolic acidosis, bicarbonate excretion from the kidney is reduced to preserve base equivalents in the body. Such reduction is facilitated by two anion exchangers: pendrin and AE1. In the kidney, pendrin (SLC26A4; $\mathrm{Cl}^{-} / \mathrm{HCO}_{3}{ }^{-}$exchanger) is expressed in the apical membrane of Type B intercalated cells. During metabolic acidosis, the expression of pendrin is significantly reduced $[65,66]$. Acid loading also appears to induce endocytosis of pendrin into the cytosol [46]. These responses subsequently decrease bicarbonate excretion into the lumen. SLC26A4 is also found to be expressed in zebrafish, and the knockdown of SLC26A4 significantly decreases $\mathrm{Cl}^{-}$ uptake after acclimation to low $\mathrm{Cl}^{-}$water [67]. Reduced base excretion (i.e., titratable base) is also observed in SLC26A4-deficient zebrafish [67]. These findings indicate the physiological significance of SLC26A4 in $\mathrm{Cl}^{-}$uptake and $\mathrm{HCO}_{3}{ }^{-}$secretion in zebrafish. However, how acidosis affects the expression and function of SLC26A4 in zebrafish are yet to be explored.

AE1 (SLC4A), which is expressed in the basolateral membrane of Type A intercalated cells, exhibits opposite response during acidosis. Expression of AE1 is increased during metabolic acidosis, thereby enhancing bicarbonate absorption into the interstitium [22,68]. In zebrafish, AE1 (i.e., AE1b) is expressed in the basolateral membrane of HRCs [21]. It has been shown that acid exposure increases mRNA expression of $a e 1 b$ in larval zebrafish [21]. Additionally, larval zebrafish experiencing AE1b knockdown have been found to exhibit a reduction in whole body $\mathrm{Na}^{+}$level and $\mathrm{H}^{+}$secretion [21]. These findings suggest that $\mathrm{AE} 1 \mathrm{~b}$ is involved in regulating $\mathrm{Na}^{+}$balance and acid secretion in zebrafish.

\subsubsection{Sodium-Bicarbonate Cotransporter (NBCe)}

In mammals, the NBCe1 ("e" stands for electrogenic) plays a crucial role in maintaining normal blood $\mathrm{pH}$ by regulating bicarbonate absorption in the proximal tubules. The mammalian NBCe1 has multiple transcript variants, including NBCe1-A (kidney-specific), NBCe1-B (intestine/ pancreas-specific) and NBCe1-C (brain-specific). Only NBCe1-A, which is expressed in the basolateral membrane of the proximal tubular cells, is thought to be involved in regulating bicarbonate absorption in the kidney $[24,25]$. It has been proposed that movement of $\mathrm{HCO}_{3}{ }^{-}$via NBCe1-A is coupled to apical NHE3 and the activity of carbonic anhydrase (CA) [69]. Specifically, luminal bicarbonate is initially protonated by NHE3 and is converted to $\mathrm{CO}_{2}$ via a dehydration reaction that is accelerated by CA4. Dissolved $\mathrm{CO}_{2}$ permeates into the cell and undergoes a reverse hydration reaction catalyzed by CA2 which converts $\mathrm{CO}_{3}{ }^{2-}$ to $\mathrm{HCO}_{3}{ }^{-}$. Subsequently, the basolateral $\mathrm{Na}^{+} / \mathrm{K}^{+}$-ATPase generates the driving force for $\mathrm{NBCe} 1-\mathrm{A}$ mediated electrogenic $\mathrm{Na}^{+}$and $\mathrm{HCO}_{3}{ }^{-}$efflux. In rat, inducing metabolic acidosis by $\mathrm{NH}_{4} \mathrm{Cl}$ loading did not affect mRNA expression of NBCe1 in the kidney [70]. However, in isolated basolateral membrane vesicles from rabbit kidney, $\mathrm{HCO}_{3}{ }^{-}$-dependent $\mathrm{Na}^{+}$uptake was increased during incubation in acidic media [71]. These results suggest that activation of the NBCe1-A by acid exposure is likely a post-transcriptional event. On the other hand, it has been documented 
that loss-of-function mutation in NBCe1-A results in proximal renal tubular acidosis [72-74]. NBCe1 null mice $\left(\mathrm{NBCe}^{-/-}\right.$) have also been found to exhibit severe metabolic acidosis and death before weaning [75].

In zebrafish, the NBCe1 protein sequence is more similar to the mammalian NBCe1-B (78\%) than NBCe1-A (73\%) [21,23]. Zebrafish NBCe1-B is expressed in the pronephros, eyes, brain, and ionocytes (i.e., NCCCs) in larvae, as well as the gills in adults [21,23]. Using a Xenopus oocyte expression system, it was demonstrated that zebrafish NBCe1-B exhibited electrogenic $\mathrm{Na}^{+}$and $\mathrm{HCO}_{3}{ }^{-}$cotransport activity [23]. As discussed previously, the transport function of NBCe1 is believed to be coupled with the activity of NHE3 and CA2. In zebrafish, these proteins (i.e., NHE3b, CA2 like-a) are expressed specifically in the HRCs $[18,59,76]$. Interestingly, NBCe1-B was shown to be expressed in NCCCs [21]. In the gills of zebrafish, mRNA level of NBCe1-B was also found to decrease following acid exposure [21]. These results suggest that NBCe1-B is unlikely involved in bicarbonate absorption in zebrafish. The functional role of NBCe1-B in the basolateral membrane of NCCCs remains to be explored.

\subsubsection{Epithelial $\mathrm{Ca}^{2+}$ Channel (ECaC)}

In mammals, transepithelial transport of $\mathrm{Ca}^{2+}$ is mediated by the transient receptor potential channels (TRPV): TRPV5 (also called ECaC) and TRPV6. TRPV5 contributes to $\mathrm{Ca}^{2+}$ transport in the kidney, while TRPV6 is more ubiquitously expressed [77]. In the mammalian kidney, the majority of $\mathrm{Ca}^{2+}$ reabsorption occurs in the proximal tubules $(\sim 60-70 \%)$ and the thick ascending limb of Henle $(\sim 10 \%)$ through the paracellular route [78]. This passive movement of $\mathrm{Ca}^{2+}$ is driven by local $\mathrm{Na}^{+}$ reabsorption, and thus $\mathrm{Ca}^{2+}$ reabsorption in these regions is not directly regulated. Although only $5-10 \%$ of total $\mathrm{Ca}^{2+}$ reabsorption occurs in the distal convoluted tubule and the collecting duct, these are the major sites for active regulation of $\mathrm{Ca}^{2+}$ transport by TRPV5 [78,79].

The uptake of $\mathrm{Ca}^{2+}$ by ECaC in the mammalian kidney is highly influenced by luminal $\mathrm{pH}$. For example, it was shown that a decrease in extracellular pH significantly inhibited $\mathrm{Ca}^{2+}$ uptake in primary cultures from rabbit cortical collecting duct [80]. Additionally, reduced $\mathrm{pH}$ was also demonstrated to inhibit $\mathrm{Ca}^{2+}$ uptake in a human embryonic kidney 293 cell line (HEK 293) expressing $\mathrm{ECaC}[81]$.

Unlike mammals, zebrafish only have one TRPV5/6 orthologue (ECaC) [31]. In zebrafish, ECaC is expressed in a subset of NaRCs, which plays an essential role in $\mathrm{Ca}^{2+}$ absorption $[31,82]$. Previous studies have shown that larval zebrafish exposed to acidic water exhibit a significant reduction in whole body $\mathrm{Ca}^{2+}$ level $[39,49]$. Such reduction is likely due to a concurrent decrease in $\mathrm{Ca}^{2+}$ uptake and an increase in $\mathrm{Ca}^{2+}$ efflux [49]. Unlike $\mathrm{Na}^{+}$uptake, which is stimulated in zebrafish following acid acclimation, $\mathrm{Ca}^{2+}$ uptake remains significantly inhibited in acidic water [49]. Interestingly, when the acid-exposed fish are returned to control $\mathrm{pH}$ water, the capacity for $\mathrm{Ca}^{2+}$ uptake is substantially increased. The increased $\mathrm{Ca}^{2+}$ uptake appears to be associated with an increased mRNA expression of ecac and density of ecac-expressing NaRCs [49]. This finding appears to be different from a previous study with mice where acid-loading $\left(\mathrm{NH}_{4} \mathrm{Cl}\right)$ resulted in a reduction in ecac expression in the kidney [50]. The mechanisms underlying the increased ecac-expressing NaRCs by acid exposure in zebrafish remain unknown. Nevertheless, acid exposure has been shown to increase whole body cortisol level in zebrafish $[49,83]$, and that cortisol is involved in promoting the proliferation of NaRCs $[84,85]$. Therefore, it is possible that the increased ecac-expressing NaRCs is due to the increased cortisol level during acid exposure. On the other hand, it has been reported that exposure to acidic water increases whole body $3^{\prime}, 5^{\prime}$-cyclic adenosine monophosphate (cAMP) levels in zebrafish [86], and that treatment with cAMP-elevating agents (i.e., 8-Br-cAMP, forskolin) significantly stimulates $\mathrm{Ca}^{2+}$ influx [87]. Future experiments should address whether cAMP plays a role in stimulating $\mathrm{Ca}^{2+}$ uptake following acid exposure. It is also noteworthy that zebrafish exposed to acidic water for 4 days exhibited over a 5-fold reduction in whole body $\mathrm{Ca}^{2+}$ level $[39,49]$. The increased $\mathrm{Ca}^{2+}$ uptake by acid exposure was only observed when the fish were returned back to normal $\mathrm{pH}$ water [49]. How zebrafish 
compensate for the loss of $\mathrm{Ca}^{2+}$ (e.g., regulation of paracellular permeability to $\mathrm{Ca}^{2+}$ ) during long-term acid exposure requires further investigation.

\subsubsection{Effects of Acidosis on the Regulation of Other Epithelial Ion Transporters}

In mammals, several other epithelial ion transporters are known to be involved in ionic compensation during metabolic acidosis, including $\mathrm{Na}^{+} /$phosphate cotransporter ( $\mathrm{NaPi}$; Pi stands for inorganic phosphate), $\mathrm{Cl}^{-} / \mathrm{HCO}_{3}{ }^{-}$exchanger, and $\mathrm{H}^{+}-\mathrm{K}^{+}$-ATPase (HKA). However, whether these transporters are involved in ion regulation in zebrafish exposed to acidic water are virtually unknown. In mammals, NaPi has three different protein families, NaPi-I, NaPi-II and NaPi-III, with NaPi-II thought to be the major player in Pi regulation in the kidney [88]. In the mammalian kidney, reabsorption of Pi occurs predominantly in the proximal tubule [89]. In rats experiencing 10 days of metabolic acidosis, renal mRNA and protein expression of $\mathrm{NaPi}$ (NaPi-II) were significantly decreased [90]. The transport activity (e.g., Jmax) of NaPi was also found to decrease [90]. In another study with the mouse kidney, however, it was demonstrated that NaPi (NaPi-IIa and NaPi-IIc) protein abundance was increased after 2 days or 10 days of acidosis [91]. The activity of NaPi was found to increase after 2 days of acidosis, but then returned to normal level after 7 days [91]. These findings suggest possible species-specific differences in the regulation of $\mathrm{NaPi}$ during acid exposure. In zebrafish, two paralogues of $\mathrm{NaPi}-\mathrm{IIb}, \mathrm{NaPi}-\mathrm{IIb} 1$ and $\mathrm{NaPi}-\mathrm{Illb} 2$, were found to express in the apical membrane of renal tubular cells [92]. NaPi-Ilb1 and NaPi-IIb2 appeared to exhibit a significant difference in their functional properties. For example, the transport activity of zebrafish NaPi-Ilb2 was shown to have a much higher affinity to Pi than NaPi-IIb1 when expressed in Xenopus oocytes [92]. $\mathrm{NaPi}-\mathrm{Ilb} 2$ was also found to be insensitive to extracellular $\mathrm{pH}$ as opposed to NaPi-IIb1 [92]. To date, no study has yet identified the expression of NaPi in zebrafish gill/ionocytes. $[93,94]$

In mammals, excretion of inorganic sulfate $(\mathrm{Si})$ is primarily regulated by the $\mathrm{Na}-\mathrm{Si}$ cotransporter in the proximal tubule [95]. During metabolic acidosis, reabsorption of $S i$ is decreased [96], which appears to be associated with decreased NaSi-1 mRNA and protein abundance, as well as reduced $\mathrm{Na}^{+}-\mathrm{Si}$ cotransport activity [96]. In zebrafish, NaSi1 mRNA is expressed in the kidney [97,98]. Functional characterization of the zebrafish NaSi1 in Xenopus oocytes suggested that the zebrafish transporter closely resembles the mammalian counterpart in terms of both affinity and transport capacity [97]. However, NaSi1 was not found to be expressed in the zebrafish gill [97].

In the mammalian kidney, $\mathrm{K}^{+}$reabsorption and acid excretion can be mediated by HKA, which is predominantly expressed in the apical membrane of intercalated cells (both type-A and type-B) and principal cells [99]. Mice experiencing metabolic acidosis exhibited an increased mRNA expression of HKA ( $\alpha$-subunits) [100]. The activity of HKA was also found to increase during metabolic acidosis $[101,102]$. The protein sequence of the mammalian $\mathrm{H}^{+}-\mathrm{K}^{+}$-ATPase $\alpha$-subunit is most similar to the zebrafish $\mathrm{Na}^{+} / \mathrm{K}^{+}$-ATPase $\alpha$-subunit isoforms 1, 2, 3, 5 and $8(\sim 63 \%-64 \%)$. Currently, however, no physiological evidence has demonstrated that these zebrafish $\mathrm{Na}^{+} / \mathrm{K}^{+}$-ATPases can function as HKA.

\section{Neuroendocrine Responses Following Acid Exposure}

In zebrafish, several neuroendocrine factors are found to be involved in ionic and acid-base regulation during acid exposure, including cortisol [38,83], endothelin 1 [103], angiotensin II [104], stanniocalcin $[49,105]$, catecholamines [106] and oestrogen-related receptor [107]. In other FW fish species, mRNA expression and/or plasma levels of thyroid hormone [108], prolactin [109], growth hormone [110] and somatolactin $[110,111]$ are found to be modulated by acid exposure. Whether these hormones are affected by acid exposure in zebrafish remain unexplored.

\subsection{Cortisol}

In mammals, the corticosteroid is a class of steroid hormones that include cortisol (glucocorticoid) and aldosterone (mineralocorticoid). Both of these hormones are synthesized in the adrenal cortex of mammals, with the aldosterone thought to be the primary factor in regulating ion reabsorption [112]. 
In mammals, activation of the mineralocorticoid receptor (MR) stimulates $\mathrm{Na}^{+}$reabsorption and $\mathrm{H}^{+}$excretion in the kidney [113]. Teleosts lack aldosterone synthase to produce aldosterone [114]. However, several in vitro studies have demonstrated that cortisol is able to activate both glucocorticoid receptor (GR) and MR [114-116].

In zebrafish larvae, GR was found to be expressed in all three ionocytes discussed above, including NaRCs [85], HRCs [83,117] and NCCCs [118]. Treatment with cortisol was shown to increase mRNA expression of genes that are involved in ion uptake or $\mathrm{H}^{+}$secretion, including ecac, ncc, nhe $3 b$, atp6v1a (encodes for $\mathrm{H}^{+}$-ATPase) and $a e 1 b[38,117]$. On the other hand, mRNA level of $11 \beta$-hydroxylase (cyp11b; encodes for a cortisol-synthesis enzyme) was found to increase following acid exposure [38]. Consistently, whole body level of cortisol was markedly increased in larval zebrafish exposed to acidic water $[49,83]$. The increased whole body cortisol level by acid exposure appears to be important in increasing acid secretion and active $\mathrm{Na}^{+}$uptake in the HRCs $[38,83,119]$. During acid exposure, cortisol was also shown to be involved in reducing diffusive $\mathrm{Na}^{+}$losses through paracellular pathways, likely by increasing the abundance of epithelial tight junctions [119]. Interestingly, the cortisol-induced effects on $\mathrm{Na}^{+}$regulation and $\mathrm{H}^{+}$secretion in zebrafish appear to be mediated by GR only.

\subsection{Endothelin}

In mammals, endothelin is involved in increasing acid excretion in the kidney during metabolic acid stress [120]. During acid loading, expression of endothelin is increased in the kidney [121], which subsequently stimulates acid secretion by enhancing the activity of NHE3 $[122,123]$ and $\mathrm{H}^{+}$-ATPase [124]. A recent study with zebrafish has also suggested that endothelin plays a critical role in regulating acid secretion [103]. The mRNA expression levels of endothelin-1 (edn1) and its receptors (ednraa) were found to increase in zebrafish exposed to acidic water. EDN1 was also shown to promote acid secretion, primarily by post-translational activation of the $\mathrm{H}^{+}$-ATPase in the HRCs of zebrafish [103]. These findings clearly demonstrate that endothelin is involved in regulating acid excretion in zebrafish.

\subsection{Oestrogen-Related Receptor}

The oestrogen-related receptor (ERR) belongs to orphan nuclear receptors which control the transcription of several genes essential in energy metabolism in mammals [125]. In zebrafish, it was recently demonstrated that ERRa is involved in promoting acid secretion in zebrafish, partially by increasing the density of HRCs [107]. erra mRNA was found to be expressed in HRCs, and that acid exposure increased its abundance [107]. ERRa was also demonstrated to positively regulate the mRNA expressions of nhe3b, atp6v1a (encodes for $\mathrm{H}^{+}$-ATPase) and $a e 1 b$ [107]. This is a novel finding on the role of ERRa in acid-base regulation in vertebrates.

\subsection{Catecholamines}

In mammals, it is well documented that catecholamines are involved in regulating $\mathrm{Na}^{+}$ reabsorption in the kidney [126]. For example, treatment with catecholamines was found to stimulate $\mathrm{Na}^{+} / \mathrm{K}^{+}$-ATPase activity in the basolateral membrane of proximal tubules isolated from rats $[127,128]$. The activity and abundance of NHE3 in the proximal tubule of rats were also shown to increase following stimulation of the $\alpha$-adrenergic receptor [129-131]. It was also demonstrated that activation of the $\beta$ adrenergic receptor increased NHE3 activity by promoting the association of the NHE regulatory factor (NHERF) with NHE3 [132]. At present, the involvement of the adrenergic system in the kidney during metabolic acidosis is not fully understood.

In larval zebrafish, both HRCs and NaRCs are innervated, and $\beta$ receptors appear to be present in both cell types $[7,106,133]$. Whether NCCCs are innervated is currently unknown. It has been demonstrated that knockdown of specific $\beta$ adrenergic receptor reduces the magnitude of increased $\mathrm{Na}^{+}$uptake in larval zebrafish exposed to acidic water [106]. The underlying mechanism of how $\beta$ adrenergic receptor elicits its effect on $\mathrm{Na}^{+}$transporters remains unclear. The downstream signalling 
cascade of $\beta$ adrenergic receptor is mediated by cAMP, and it has been shown that treatment with cAMP-elevating agents increases $\mathrm{Na}^{+}$uptake in larval zebrafish [86]. Whole body cAMP level has also been found to increase in larval zebrafish acutely exposed to acidic water [86]. These findings suggest that activation of the $\beta$ adrenergic system during acid exposure increases whole body cAMP level, which subsequently increases $\mathrm{Na}^{+}$uptake. Using a morpholino knockdown approach, it has also been demonstrated that cAMP-stimulated $\mathrm{Na}^{+}$uptake is likely mediated by both NHE3b and NCC [86].

\subsection{Angiotensin II}

In mammals, the renin-angiotensin system (RAS) plays a critical role in regulating ion and fluid reabsorption in the kidney [134]. Angiotensinogen, which is primarily released from the liver, is first cleaved to angiotensin-I (ANG-I) by the enzyme renin secreted in the kidney. ANG-I is then converted to the biologically active form ANG-II by angiotensin-converting enzyme (ACE). In the mammalian kidney, ANG-II is found to stimulate NHE3, $\mathrm{H}^{+}$-ATPase and NCC [135-140]. A previous study with larval zebrafish has demonstrated that whole body ANG-II level is elevated following acid exposure [104]. It has also been shown that translational gene knockdown of renin significantly attenuated the increased $\mathrm{Na}^{+}$uptake by acute acid exposure [104]. These findings suggest that the RAS is involved in promoting $\mathrm{Na}^{+}$uptake under acidic environment. On the other hand, treatment with exogenous ANG-II was found to increase the mRNA expression of $n c c$, but not nhe3b or atp6v1a (encodes for $\mathrm{H}^{+}$-ATPase) [104]. Interestingly, NCC appears to play a critical role in the rapid compensatory regulation of $\mathrm{Na}^{+}$uptake following acute acid exposure [26]. In mammals, ANG-II is proposed to activate NCC through post-translational regulation [141]. Whether similar mechanism occurs in zebrafish NCC has yet to be explored. The expression of ANG-II receptors in ionocytes of zebrafish also awaits further study.

\subsection{Stanniocalcin}

In mammals, the principal cells in the collecting duct are one of the primary sources of stanniocalcin, which acts as a hypocalcemic factor to decrease $\mathrm{Ca}^{2+}$ uptake in the intestine and kidney $[142,143]$. In zebrafish, stanniocalcin (i.e., STC1) is known to negatively regulate ecac expression and thereby reducing $\mathrm{Ca}^{2+}$ uptake [144]. Recently, this hormone has also been proposed to regulate acid excretion and $\mathrm{Ca}^{2+}$ transport following acid exposure [49,105]. Exposure to acidic water appears to specifically reduce mRNA expression of stc1, but not other $\mathrm{Ca}^{2+}$-regulatory hormones (e.g., parathyroid hormone, calcitonin) $[49,105]$. The reduced expression of $s t c 1$ may potentially promote $\mathrm{Ca}^{2+}$ uptake by increasing ecac expression and density of ecac-expressing NaRCs during acid exposure [49,105]. Additionally, acid excretion is significantly reduced in zebrafish overexpressing STC1, possibly owing to its inhibitory effects on HRCs differentiation from epidermal stem cells [105]. These novel findings from the zebrafish model provide new understanding of the role of STC1 during metabolic acidosis.

\section{Conclusions and Perspectives}

The zebrafish has emerged as a useful in vivo model to investigate the cellular and molecular mechanisms underlying the regulation of ionic and acid-base homeostasis in vertebrates. Previous research efforts with the gill/skin of zebrafish have greatly improved our fundamental understanding of the compensatory mechanisms, ion transport function, and neuroendocrine responses during metabolic acidosis. However, it is also important to recognize the differences in the expression pattern and functional regulation of some of the ion transporters between zebrafish and higher vertebrates. For examples, (i) $\mathrm{H}^{+}$-ATPase is expressed in both the apical and basolateral membranes of mammalian intercalated cells, whereas it is expressed only in the apical membrane of zebrafish HRCs; (ii) NaPi and $\mathrm{NaSi}$ are absent in the zebrafish gill/ionocytes; (iii) compared to zebrafish, mammals do not appear to compensate for the increased $\mathrm{Ca}^{2+}$ loss during acid loading. These differences may ultimately contribute to different strategies employed by zebrafish and mammals in regulating systemic acid-base and ion homeostasis during metabolic acidosis. 
Currently, studies on the ionic and acid-base regulation in zebrafish are mostly limited to early developmental stages. Ion regulation occurs in the skin of the yolk sac in larvae, as opposed to the gills, intestine, and kidney in adults. Therefore, future studies should also address the regulation of ionic and acid-base balance in adult zebrafish. Additionally, a number of areas still remain largely unknown, and should be addressed in future investigations: (i) identification of the localization of several hormone receptors (e.g., receptors for STC1 and ANG-II) in zebrafish ionocytes; (ii) mechanism of environmental and intracellular acid sensing; (iii) responses of other neuroendocrine factors that are thought to be important in ionic and acid-base regulation in FW fish (e.g., thyroid hormone, prolactin, growth hormone, and somatolactin); (iv) post-translational regulation of ion transporters/channels; (v) potential crosstalk among neuroendocrine factors; and (vi) role of transcription factors and hormones in ionocyte differentiation/proliferation during acidosis. Furthermore, previous research on the effects of acidosis in zebrafish is limited to $\mathrm{Na}^{+}$and $\mathrm{Ca}^{2+}$, and to a lesser extent $\mathrm{Cl}^{-}$. Future studies should also address the regulation of other major ions (e.g., $\mathrm{Mg}^{2+}$ and $\mathrm{K}^{+}$) during acid exposure.

Acknowledgments: Our original research was supported by the Canada Research Chairs Program and a Discovery Grant from the Natural Sciences and Engineering Research Council of Canada (NSERC) to Raymond W. M. Kwong. Processing charge for this article was supported by the York University Libraries Open Access Author Fund.

Author Contributions: Lletta Lewis and Raymond W. M. Kwong drafted the manuscript; Lletta Lewis and Raymond W. M. Kwong edited and revised the manuscript; Lletta Lewis and Raymond W. M. Kwong approved the final version of the manuscript.

Conflicts of Interest: The authors declare no conflict of interest.

\section{References}

1. Kwong, R.W.M.; Kumai, Y.; Perry, S.F. The physiology of fish at low pH: The zebrafish as a model system. J. Exp. Biol. 2014, 217, 651-662. [CrossRef] [PubMed]

2. Wagner, C.A.; Finberg, K.E.; Breton, S.; Marshansky, V.; Brown, D.; Geibel, J.P. Renal Vacuolar H-ATPase. Physiol. Rev. 2004, 84, 1263-1314. [CrossRef] [PubMed]

3. Wagner, C.A.; Devuyst, O.; Bourgeois, S.; Mohebbi, N. Regulated acid-base transport in the collecting duct. Pflügers Arch. 2009, 458, 137-156. [CrossRef] [PubMed]

4. Bobulescu, I.A.; Moe, O.W. Na ${ }^{+} / \mathrm{H}^{+}$exchangers in renal regulation of acid-base balance. Semin. Nephrol. 2006, 26, 334-344. [CrossRef] [PubMed]

5. Guh, Y.-J.; Lin, C.-H.; Hwang, P.-P. Osmoregulation in zebrafish: Ion transport mechanisms and functional regulation. EXCLI J. 2015, 14, 627-659. [CrossRef] [PubMed]

6. Lin, C.-H.; Hwang, P.-P. The Control of Calcium Metabolism in Zebrafish (Danio rerio). Int. J. Mol. Sci. 2016, 17, 1783. [CrossRef] [PubMed]

7. Kwong, R.W.M.; Kumai, Y.; Perry, S.F. Neuroendocrine control of ionic balance in zebrafish. Gen. Comp. Endocrinol. 2016, 234, 40-46. [CrossRef] [PubMed]

8. Hwang, P.-P. Ion uptake and acid secretion in zebrafish (Danio rerio). J. Exp. Biol. 2009, 212, 1745-1752. [CrossRef] [PubMed]

9. Perry, S.; Kumai, Y.; Porteus, C.S.; Tzaneva, V.; Kwong, R.W.M. An emerging role for gasotransmitters in the control of breathing and ionic regulation in fish. J. Comp. Physiol. B 2016, 186, 145-159. [CrossRef] [PubMed]

10. Guh, Y.-J.; Hwang, P.-P. Insights into molecular and cellular mechanisms of hormonal actions on fish ion regulation derived from the zebrafish model. Gen. Comp. Endocrinol. 2017, 251, 12-20. [CrossRef] [PubMed]

11. Hwang, P.-P.; Chou, M.-Y. Zebrafish as an animal model to study ion homeostasis. Pflugers Arch. 2013, 465, 1233-1247. [CrossRef] [PubMed]

12. Lin, L.-Y.; Horng, J.-L.; Kunkel, J.G.; Hwang, P.-P. Proton pump-rich cell secretes acid in skin of zebrafish larvae. Am. J. Physiol. Cell Physiol. 2005, 290, C371-C378. [CrossRef] [PubMed]

13. Horng, J.-L.; Lin, L.-Y.; Huang, C.-J.; Katoh, F.; Kaneko, T.; Hwang, P.-P. Knockdown of V-ATPase subunit A (atp6v1a) impairs acid secretion and ion balance in zebrafish (Danio rerio). Am. J. Physiol. Integr. Comp. Physiol. 2007, 292, R2068-R2076. [CrossRef] [PubMed]

14. Brown, D.; Hirsch, S.; Gluck, S. Localization of a proton-pumping ATPase in rat kidney. J. Clin. Investig. 1988, 82, 2114-2126. [CrossRef] [PubMed] 
15. Brown, D.; Hirscht, S.; Gluck, S. An $\mathrm{H}^{+}$-ATPase in opposite plasma membrane domains in kidney epithelial cell subpopulations. Nature 1988, 331, 622-624. [CrossRef] [PubMed]

16. Alper, S.L.; Natale, J.; Gluck, S.; Lodish, H.F.; Brown, D. Subtypes of intercalated cells in rat kidney collecting duct defined by antibodies against erythroid band 3 and renal vacuolar $\mathrm{H}^{+}$-ATPase. Proc. Natl. Acad. Sci. USA 1989, 86, 5429-5433. [CrossRef] [PubMed]

17. Yan, J.-J.; Chou, M.-Y.; Kaneko, T.; Hwang, P.-P. Gene expression of $\mathrm{Na}^{+} / \mathrm{H}^{+}$exchanger in zebrafish $\mathrm{H}^{+}$-ATPase-rich cells during acclimation to low-Na+ and acidic environments. Am. J. Physiol. Cell Physiol. 2007, 293, C1814-C1823. [CrossRef] [PubMed]

18. Ito, Y.; Kobayashi, S.; Nakamura, N.; Miyagi, H.; Esaki, M.; Hoshijima, K.; Hirose, S. Close Association of Carbonic Anhydrase (CA2a and CA15a), Na(+)/H(+) Exchanger (Nhe3b), and Ammonia Transporter Rhcg1 in Zebrafish Ionocytes Responsible for $\mathrm{Na}(+)$ Uptake. Front. Physiol. 2013, 4, 59. [CrossRef] [PubMed]

19. Biemesderfer, D.; Pizzonia, J.; Abu-Alfa, A.; Exner, M.; Reilly, R.; Igarashi, P.; Aronson, P.S. NHE3: A Na ${ }^{+} / \mathrm{H}^{+}$ exchanger isoform of renal brush border. Am. J. Physiol. 1993, 265, F736-F742. [CrossRef] [PubMed]

20. Amemiya, M.; Loffing, J.; Lötscher, M.; Kaissling, B.; Alpern, R.J.; Moe, O.W. Expression of NHE-3 in the apical membrane of rat renal proximal tubule and thick ascending limb. Kidney Int. 1995, 48, 1206-1215. [CrossRef] [PubMed]

21. Lee, Y.-C.; Yan, J.-J.; Cruz, S.A.; Horng, J.-L.; Hwang, P.-P. Anion exchanger 1b, but not sodium-bicarbonate cotransporter $1 \mathrm{~b}$, plays a role in transport functions of zebrafish $\mathrm{H}^{+}$-ATPase-rich cells. Am. J. Physiol. Cell Physiol. 2011, 300, C295-C307. [CrossRef] [PubMed]

22. Fejes-Tóth, G.; Chen, W.R.; Rusvai, E.; Moser, T.; Náray-Fejes-Tóth, A. Differential expression of AE1 in renal $\mathrm{HCO}_{3}$-secreting and -reabsorbing intercalated cells. J. Biol. Chem. 1994, 269, 26717-26721. [PubMed]

23. Sussman, C.R.; Zhao, J.; Plata, C.; Lu, J.; Daly, C.; Angle, N.; DiPiero, J.; Drummond, I.A.; Liang, J.O.; Boron, W.F.; et al. Cloning, localization, and functional expression of the electrogenic $\mathrm{Na}^{+}$bicarbonate cotransporter (NBCe1) from zebrafish. Am. J. Physiol. Cell Physiol. 2009, 297, C865-C875. [CrossRef] [PubMed]

24. Schmitt, B.M.; Biemesderfer, D.; Romero, M.F.; Boulpaep, E.L.; Boron, W.F. Immunolocalization of the electrogenic $\mathrm{Na}^{+}-\mathrm{HCO}_{3}$ cotransporter in mammalian and amphibian kidney. Am. J. Physiol. 1999, 276, F27-F38. [PubMed]

25. Abuladze, N.; Song, M.; Pushkin, A.; Newman, D.; Lee, I.; Nicholas, S.; Kurtz, I. Structural organization of the human NBC1 gene: KNBC1 is transcribed from an alternative promoter in intron 3. Gene 2000, 251, 109-122. [CrossRef]

26. Kwong, R.W.M.; Perry, S.F. A role for sodium-chloride cotransporters in the rapid regulation of ion uptake following acute environmental acidosis: New insights from the zebrafish model. Am. J. Physiol. Cell Physiol. 2016, 311, C931-C941. [CrossRef] [PubMed]

27. Wang, Y.-F.; Tseng, Y.-C.; Yan, J.-J.; Hiroi, J.; Hwang, P.-P. Role of SLC12A10.2, a Na-Cl cotransporter-like protein, in a $\mathrm{Cl}$ uptake mechanism in zebrafish (Danio rerio). Am. J. Physiol. Regul. Integr. Comp. Physiol. 2009, 296, R1650-R1660. [CrossRef] [PubMed]

28. Gamba, G. The thiazide-sensitive $\mathrm{Na}^{+}-\mathrm{Cl}^{-}$cotransporter: Molecular biology, functional properties, and regulation by WNKs. Am. J. Physiol. Ren. Physiol. 2009, 297, F838-F848. [CrossRef] [PubMed]

29. Ellison, D.H.; Velázquez, H.; Wright, F.S. Thiazide-sensitive sodium chloride cotransport in early distal tubule. Am. J. Physiol. 1987, 253, F546-F554. [CrossRef] [PubMed]

30. Plotkin, M.D.; Kaplan, M.R.; Verlander, J.W.; Lee, W.S.; Brown, D.; Poch, E.; Gullans, S.R.; Hebert, S.C. Localization of the thiazide sensitive $\mathrm{Na}-\mathrm{Cl}$ cotransporter, rTSC1 in the rat kidney. Kidney Int. 1996, 50, 174-183. [CrossRef] [PubMed]

31. Pan, T.-C.; Liao, B.-K.; Huang, C.-J.; Lin, L.-Y.; Hwang, P.-P. Epithelial Ca ${ }^{2+}$ channel expression and Ca ${ }^{2+}$ uptake in developing zebrafish. Am. J. Physiol. Regul. Integr. Comp. Physiol. 2005, 289, R1202-R1211. [CrossRef] [PubMed]

32. Liao, B.-K.; Deng, A.-N.; Chen, S.-C.; Chou, M.-Y.; Hwang, P.-P. Expression and water calcium dependence of calcium transporter isoforms in zebrafish gill mitochondrion-rich cells. BMC Genom. 2007, 8, 354. [CrossRef] [PubMed]

33. Hoenderop, J.G.; van der Kemp, A.W.; Hartog, A.; van de Graaf, S.F.; van Os, C.H.; Willems, P.H.; Bindels, R.J. Molecular identification of the apical $\mathrm{Ca}^{2+}$ channel in 1,25-dihydroxyvitamin D3-responsive epithelia. J. Biol. Chem. 1999, 274, 8375-8378. [CrossRef] [PubMed] 
34. Peng, J.B.; Chen, X.Z.; Berger, U.V.; Vassilev, P.M.; Brown, E.M.; Hediger, M.A. A rat kidney-specific calcium transporter in the distal nephron. J. Biol. Chem. 2000, 275, 28186-28194. [CrossRef] [PubMed]

35. Hoenderop, J.G.; Hartog, A.; Stuiver, M.; Doucet, A.; Willems, P.H.; Bindels, R.J. Localization of the epithelial $\mathrm{Ca}(2+)$ channel in rabbit kidney and intestine. J. Am. Soc. Nephrol. 2000, 11, 1171-1178. [PubMed]

36. Baxendale-Cox, L.M.; Duncan, R.L.; Liu, X.; Baldwin, K.; Els, W.J.; Helman, S.I. Steroid hormone-dependent expression of blocker-sensitive ENaCs in apical membranes of A6 epithelia. Am. J. Physiol. 1997, 273, C1650-C1656. [CrossRef] [PubMed]

37. Garty, H.; Palmer, L.G. Epithelial sodium channels: Function, structure, and regulation. Physiol. Rev. 1997, 77, 359-396. [CrossRef] [PubMed]

38. Lin, C.-H.; Shih, T.-H.; Liu, S.-T.; Hsu, H.-H.; Hwang, P.-P. Cortisol Regulates Acid Secretion of $\mathrm{H}(+)$-ATPase-rich Ionocytes in Zebrafish (Danio rerio) Embryos. Front. Physiol. 2015, 6, 328. [CrossRef] [PubMed]

39. Horng, J.-L.; Lin, L.-Y.; Hwang, P.-P. Functional regulation of $\mathrm{H}^{+}$-ATPase-rich cells in zebrafish embryos acclimated to an acidic environment. Am. J. Physiol. Cell Physiol. 2009, 296, C682-C692. [CrossRef] [PubMed]

40. Fejes-Tóth, G.; Náray-Fejes-Tóth, A. Effect of acid/base balance on H-ATPase 31 kD subunit mRNA levels in collecting duct cells. Kidney Int. 1995, 48, 1420-1426. [CrossRef] [PubMed]

41. Verlander, J.W.; Madsen, K.M.; Cannon, J.K.; Tisher, C.C. Activation of acid-secreting intercalated cells in rabbit collecting duct with ammonium chloride loading. Am. J. Physiol. 1994, 266, F633-F645. [CrossRef] [PubMed]

42. Kumai, Y.; Perry, S.F. Ammonia excretion via Rhcg1 facilitates $\mathrm{Na}^{+}$uptake in larval zebrafish, Danio rerio, in acidic water. Am. J. Physiol. Regul. Integr. Comp. Physiol. 2011, 301, R1517-R1528. [CrossRef] [PubMed]

43. Laghmani, K.; Borensztein, P.; Ambühl, P.; Froissart, M.; Bichara, M.; Moe, O.W.; Alpern, R.J.; Paillard, M. Chronic metabolic acidosis enhances NHE-3 protein abundance and transport activity in the rat thick ascending limb by increasing NHE-3 mRNA. J. Clin. Investig. 1997, 99, 24-30. [CrossRef] [PubMed]

44. Ambuhl, P.M.; Amemiya, M.; Danczkay, M.; Lotscher, M.; Kaissling, B.; Moe, O.W.; Preisig, P.A.; Alpern, R.J. Chronic metabolic acidosis increases NHE3 protein abundance in rat kidney. Am. J. Physiol. 1996, 271, F917-F925. [CrossRef] [PubMed]

45. Preisig, P.A.; Alpern, R.J. Chronic metabolic acidosis causes an adaptation in the apical membrane $\mathrm{Na} / \mathrm{H}$ antiporter and basolateral membrane $\mathrm{Na}\left(\mathrm{HCO}_{3}\right)_{3}$ symporter in the rat proximal convoluted tubule. J. Clin. Investig. 1988, 82, 1445-1453. [CrossRef] [PubMed]

46. Purkerson, J.M.; Tsuruoka, S.; Zachary Suter, D.; Nakamori, A.; Schwartz, G.J. Adaptation to metabolic acidosis and its recovery are associated with changes in anion exchanger distribution and expression in the cortical collecting duct. Kidney Int. 2010, 78, 993-1005. [CrossRef] [PubMed]

47. Faroqui, S.; Sheriff, S.; Amlal, H. Metabolic acidosis has dual effects on sodium handling by rat kidney. Am. J. Physiol. Ren. Physiol. 2006, 291, F322-F331. [CrossRef] [PubMed]

48. Chang, W.-J.; Wang, Y.-F.; Hu, H.-J.; Wang, J.-H.; Lee, T.-H.; Hwang, P.-P. Compensatory regulation of $\mathrm{Na}^{+}$ absorption by $\mathrm{Na}^{+} / \mathrm{H}^{+}$exchanger and $\mathrm{Na}^{+}-\mathrm{Cl}^{-}$cotransporter in zebrafish (Danio rerio). Front. Zool. 2013, 10, 46. [CrossRef] [PubMed]

49. Kumai, Y.; Kwong, R.W.M.; Perry, S.F. A role for transcription factor glial cell missing 2 in $\mathrm{Ca}^{2+}$ homeostasis in zebrafish, Danio rerio. Pflügers Arch. 2015, 467, 753-765. [CrossRef] [PubMed]

50. Nijenhuis, T.; Renkema, K.Y.; Hoenderop, J.G.J.; Bindels, R.J.M. Acid-base status determines the renal expression of $\mathrm{Ca}^{2+}$ and $\mathrm{Mg}^{2+}$ transport proteins. J. Am. Soc. Nephrol. 2006, 17, 617-626. [CrossRef] [PubMed]

51. Milligan, C.L.; Wood, C.M. Disturbances in Haematology, Fluid Volume Distribution and Circulatory Function Associated with Low Environmental pH in the Rainbow Trout, Salmo Gairdneri. J. Exp. Biol. 1982, 99, 397-415.

52. Wood, C.M. The physiological problems of fish in acid waters. In Acid Toxicity and Aquatic Animals; Morris, R., Taylor, E.W., Brown, D.J.A., Brown, J.A., Eds.; Cambridge University Press: Cambridge, UK, 1989; pp. 125-152.

53. Evans, D.H.; Piermarini, P.M.; Choe, K.P. The multifunctional fish gill: Dominant site of gas exchange, osmoregulation, acid-base regulation, and excretion of nitrogenous waste. Physiol. Rev. 2005, 85, 97-177. [CrossRef] [PubMed]

54. Wright, P.A.; Wood, C.M. Seven things fish know about ammonia and we don't. Respir. Physiol. Neurobiol. 2012, 184, 231-240. [CrossRef] [PubMed] 
55. Kumai, Y.; Perry, S.F. Mechanisms and regulation of $\mathrm{Na}^{+}$uptake by freshwater fish. Respir. Physiol. Neurobiol. 2012, 184, 249-256. [CrossRef] [PubMed]

56. Hwang, P.-P.; Lee, T.-H.; Lin, L.-Y. Ion regulation in fish gills: Recent progress in the cellular and molecular mechanisms. Am. J. Physiol. Regul. Integr. Comp. Physiol. 2011, 301, R28-R47. [CrossRef] [PubMed]

57. Meneton, P. Comparative roles of the renal apical sodium transport systems in blood pressure control. J. Am. Soc. Nephrol. 2000, 11 (Suppl. S1), S135-S139. [PubMed]

58. Shih, T.-H.; Horng, J.-L.; Liu, S.-T.; Hwang, P.-P.; Lin, L.-Y. Rhcg1 and NHE3b are involved in ammonium-dependent sodium uptake by zebrafish larvae acclimated to low-sodium water. Am. J. Physiol. Regul. Integr. Comp. Physiol. 2012, 302, R84-R93. [CrossRef] [PubMed]

59. Esaki, M.; Hoshijima, K.; Kobayashi, S.; Fukuda, H.; Kawakami, K.; Hirose, S. Visualization in zebrafish larvae of $\mathrm{Na}^{+}$uptake in mitochondria-rich cells whose differentiation is dependent on foxi3a. Am. J. Physiol. Regul. Integr. Comp. Physiol. 2006, 292, R470-R480. [CrossRef] [PubMed]

60. Bachmann, S.; Bostanjoglo, M.; Schmitt, R.; Ellison, D.H. Sodium transport-related proteins in the mammalian distal nephron—Distribution, ontogeny and functional aspects. Anat. Embryol. 1999, 200, 447-468. [CrossRef] [PubMed]

61. Fanestil, D.D.; Vaughn, D.A.; Blakely, P. Metabolic acid-base influences on renal thiazide receptor density. Am. J. Physiol. 1997, 272, R2004-R2008. [CrossRef] [PubMed]

62. Kim, G.H.; Martin, S.W.; Fernández-Llama, P.; Masilamani, S.; Packer, R.K.; Knepper, M.A. Long-term regulation of renal Na-dependent cotransporters and ENaC: Response to altered acid-base intake. Am. J. Physiol. Ren. Physiol. 2000, 279, F459-F467. [CrossRef] [PubMed]

63. Fang, Y.-W.; Yang, S.-S.; Cheng, C.-J.; Tseng, M.-H.; Hsu, H.-M.; Lin, S.-H. Chronic Metabolic Acidosis Activates Renal Tubular Sodium Chloride Cotransporter through Angiotension II-dependent WNK4-SPAK Phosphorylation Pathway. Sci. Rep. 2016, 6, 18360. [CrossRef] [PubMed]

64. Kwong, R.W.M.; Perry, S.F. The tight junction protein claudin-b regulates epithelial permeability and sodium handling in larval zebrafish, Danio rerio. Am. J. Physiol. Integr. Comp. Physiol. 2013, 304, R504-R513. [CrossRef] [PubMed]

65. Petrovic, S.; Wang, Z.; Ma, L.; Soleimani, M. Regulation of the apical $\mathrm{Cl}^{-} / \mathrm{HCO}$ exchanger pendrin in rat cortical collecting duct in metabolic acidosis. Am. J. Physiol. Ren. Physiol. 2003, 284, F103-F112. [CrossRef] [PubMed]

66. Wagner, C.A.; Finberg, K.E.; Stehberger, P.A.; Lifton, R.P.; Giebisch, G.H.; Aronson, P.S.; Geibel, J.P. Regulation of the expression of the $\mathrm{Cl}^{-}$/anion exchanger pendrin in mouse kidney by acid-base status. Kidney Int. 2002, 62, 2109-2117. [CrossRef] [PubMed]

67. Bayaa, M.; Vulesevic, B.; Esbaugh, A.; Braun, M.; Ekker, M.E.; Grosell, M.; Perry, S.F. The involvement of SLC26 anion transporters in chloride uptake in zebrafish (Danio rerio) larvae. J. Exp. Biol. 2009, 212, 3283-3295. [CrossRef] [PubMed]

68. Huber, S.; Asan, E.; Jöns, T.; Kerscher, C.; Püschel, B.; Drenckhahn, D. Expression of rat kidney anion exchanger 1 in type A intercalated cells in metabolic acidosis and alkalosis. Am. J. Physiol. 1999, 277, F841-F849. [CrossRef] [PubMed]

69. Boron, W.F. Acid-Base Transport by the Renal Proximal Tubule. J. Am. Soc. Nephrol. 2006, 17, $2368-2382$. [CrossRef] [PubMed]

70. Burnham, C.E.; Flagella, M.; Wang, Z.; Amlal, H.; Shull, G.E.; Soleimani, M. Cloning, renal distribution, and regulation of the rat $\mathrm{Na}^{+}-\mathrm{HCO}_{3}{ }^{-}$cotransporter. Am. J. Physiol. 1998, 274, F1119-F1126. [PubMed]

71. Soleimani, M.; Bizal, G.L.; McKinney, T.D.; Hattabaugh, Y.J. Effect of in vitro metabolic acidosis on luminal $\mathrm{Na}^{+} / \mathrm{H}^{+}$exchange and basolateral $\mathrm{Na}^{+}: \mathrm{HCO}_{3}{ }^{-}$cotransport in rabbit kidney proximal tubules. J. Clin. Investig. 1992, 90, 211-218. [CrossRef] [PubMed]

72. Igarashi, T.; Inatomi, J.; Sekine, T.; Cha, S.H.; Kanai, Y.; Kunimi, M.; Tsukamoto, K.; Satoh, H.; Shimadzu, M.; Tozawa, F.; et al. Mutations in SLC4A4 cause permanent isolated proximal renal tubular acidosis with ocular abnormalities. Nat. Genet. 1999, 23, 264-266. [CrossRef] [PubMed]

73. Dinour, D.; Chang, M.-H.; Satoh, J.; Smith, B.L.; Angle, N.; Knecht, A.; Serban, I.; Holtzman, E.J.; Romero, M.F. A Novel Missense Mutation in the Sodium Bicarbonate Cotransporter (NBCe1/SLC4A4) Causes Proximal Tubular Acidosis and Glaucoma through Ion Transport Defects. J. Biol. Chem. 2004, 279, 52238-52246. [CrossRef] [PubMed] 
74. Myers, E.J.; Yuan, L.; Felmlee, M.A.; Lin, Y.-Y.; Jiang, Y.; Pei, Y.; Wang, O.; Li, M.; Xing, X.-P.; Marshall, A.; et al. A novel mutant $\mathrm{Na}^{+} / \mathrm{HCO}_{3}{ }^{-}$cotransporter $\mathrm{NBCe} 1$ in a case of compound-heterozygous inheritance of proximal renal tubular acidosis. J. Physiol. 2016, 594, 6267-6286. [CrossRef] [PubMed]

75. Gawenis, L.R.; Bradford, E.M.; Prasad, V.; Lorenz, J.N.; Simpson, J.E.; Clarke, L.L.; Woo, A.L.; Grisham, C.; Sanford, L.P.; Doetschman, T.; et al. Colonic anion secretory defects and metabolic acidosis in mice lacking the NBC1 $\mathrm{Na}^{+} / \mathrm{HCO}^{-}$cotransporter. J. Biol. Chem. 2007, 282, 9042-9052. [CrossRef] [PubMed]

76. Hsiao, C.-D.; You, M.-S.; Guh, Y.-J.; Ma, M.; Jiang, Y.-J.; Hwang, P.-P. A Positive Regulatory Loop between foxi3a and foxi3b Is Essential for Specification and Differentiation of Zebrafish Epidermal Ionocytes. PLoS ONE 2007, 2, e302. [CrossRef] [PubMed]

77. Van de Graaf, S.F.J.; Bindels, R.J.M.; Hoenderop, J.G.J. Physiology of epithelial $\mathrm{Ca}^{2+}$ and $\mathrm{Mg}^{2+}$ transport. Rev. Physiol. Biochem. Pharmacol. 2007, 158, 77-160. [PubMed]

78. Blaine, J.; Chonchol, M.; Levi, M. Renal control of calcium, phosphate, and magnesium homeostasis. Clin. J. Am. Soc. Nephrol. 2015, 10, 1257-1272. [CrossRef] [PubMed]

79. Dimke, H.; Hoenderop, J.G.J.; Bindels, R.J.M. Molecular basis of epithelial $\mathrm{Ca}^{2+}$ and $\mathrm{Mg}^{2+}$ transport: Insights from the TRP channel family. J. Physiol. 2011, 589, 1535-1542. [CrossRef] [PubMed]

80. Bindels, R.J.; Hartog, A.; Abrahamse, S.L.; Van Os, C.H. Effects of pH on apical calcium entry and active calcium transport in rabbit cortical collecting system. Am. J. Physiol. 1994, 266, F620-F627. [CrossRef] [PubMed]

81. Muller, D.; Hoenderop, J.G.J.; van Os, C.H.; Bindels, R.J.M. The epithelial calcium channel, ECaC1: Molecular details of a novel player in renal calcium handling. Nephrol. Dial. Transplant. 2001, 16, 1329-1335. [CrossRef] [PubMed]

82. Vanoevelen, J.; Janssens, A.; Huitema, L.F.A.; Hammond, C.L.; Metz, J.R.; Flik, G.; Voets, T.; Schulte-Merker, S. Trpv5/6 is vital for epithelial calcium uptake and bone formation. FASEB J. 2011, 25, 3197-3207. [CrossRef] [PubMed]

83. Kumai, Y.; Nesan, D.; Vijayan, M.M.; Perry, S.F. Cortisol regulates $\mathrm{Na}^{+}$uptake in zebrafish, Danio rerio, larvae via the glucocorticoid receptor. Mol. Cell. Endocrinol. 2012, 364, 113-125. [CrossRef] [PubMed]

84. Cruz, S.A.; Lin, C.-H.; Chao, P.-L.; Hwang, P.-P. Glucocorticoid receptor, but not mineralocorticoid receptor, mediates cortisol regulation of epidermal ionocyte development and ion transport in zebrafish (Danio rerio). PLoS ONE 2013, 8, e77997. [CrossRef] [PubMed]

85. Cruz, S.A.; Chao, P.-L.; Hwang, P.-P. Cortisol promotes differentiation of epidermal ionocytes through Foxi3 transcription factors in zebrafish (Danio rerio). Comp. Biochem. Physiol. Part A Mol. Integr. Physiol. 2013, 164, 249-257. [CrossRef] [PubMed]

86. Kumai, Y.; Kwong, R.W.M.; Perry, S.F. The role of cAMP-mediated intracellular signaling in regulating $\mathrm{Na}^{+}$ uptake in zebrafish larvae. Am. J. Physiol. Integr. Comp. Physiol. 2014, 306, R51-R60. [CrossRef] [PubMed]

87. Kwong, R.W.M.; Perry, S.F. Hydrogen sulfide promotes calcium uptake in larval zebrafish. Am. J. Physiol. Cell Physiol. 2015, 309, C60-C69. [CrossRef] [PubMed]

88. Werner, A.; Dehmelt, L.; Nalbant, P. $\mathrm{Na}^{+}$-dependent phosphate cotransporters: The NaPi protein families. J. Exp. Biol. 1998, 201, 3135-3142. [PubMed]

89. Biber, J.; Hernando, N.; Forster, I.; Murer, H. Regulation of phosphate transport in proximal tubules. Pflügers Arch. 2009, 458, 39-52. [CrossRef] [PubMed]

90. Ambühl, P.M.; Zajicek, H.K.; Wang, H.; Puttaparthi, K.; Levi, M. Regulation of renal phosphate transport by acute and chronic metabolic acidosis in the rat. Kidney Int. 1998, 53, 1288-1298. [CrossRef] [PubMed]

91. Nowik, M.; Picard, N.; Stange, G.; Capuano, P.; Tenenhouse, H.S.; Biber, J.; Murer, H.; Wagner, C.A. Renal phosphaturia during metabolic acidosis revisited: Molecular mechanisms for decreased renal phosphate reabsorption. Pflügers Arch. 2008, 457, 539-549. [CrossRef] [PubMed]

92. Graham, C.; Nalbant, P.; Schölermann, B.; Hentschel, H.; Kinne, R.K.H.; Werner, A. Characterization of a type IIb sodium-phosphate cotransporter from zebrafish (Danio rerio) kidney. Am. J. Physiol. Ren. Physiol. 2003, 284, F727-F736. [CrossRef] [PubMed]

93. Nalbant, P.; Boehmer, C.; Dehmelt, L.; Wehner, F.; Werner, A. Functional characterization of a Na ${ }^{+}$-phosphate cotransporter (NaPi-II) from zebrafish and identification of related transcripts. J. Physiol. 1999, 520 Pt 1, 79-89. [CrossRef] [PubMed]

94. Beene, L.C.; Halluer, J.; Yoshinaga, M.; Hamdi, M.; Liu, Z. Pentavalent arsenate transport by zebrafish phosphate transporter NaPi-Ilb1. Zebrafish 2011, 8, 125-131. [CrossRef] [PubMed] 
95. Ullrich, K.J.; Murer, H. Sulphate and phosphate transport in the renal proximal tubule. Philos. Trans. R. Soc. Lond. B Biol. Sci. 1982, 299, 549-558. [CrossRef] [PubMed]

96. Puttaparthi, K.; Markovich, D.; Halaihel, N.; Wilson, P.; Zajicek, H.K.; Wang, H.; Biber, J.; Murer, H.; Rogers, T.; Levi, M. Metabolic acidosis regulates rat renal Na-Si cotransport activity. Am. J. Physiol. 1999, 276, C1398-C1404. [CrossRef] [PubMed]

97. Markovich, D.; Romano, A.; Storelli, C.; Verri, T. Functional and structural characterization of the zebrafish $\mathrm{Na}^{+}$-sulfate cotransporter 1 (NaS1) cDNA and gene (slc13a1). Physiol. Genom. 2008, 34, 256-264. [CrossRef] [PubMed]

98. Wingert, R.A.; Selleck, R.; Yu, J.; Song, H.-D.; Chen, Z.; Song, A.; Zhou, Y.; Thisse, B.; Thisse, C.; McMahon, A.P.; et al. The cdx Genes and Retinoic Acid Control the Positioning and Segmentation of the Zebrafish Pronephros. PLoS Genet. 2007, 3, e189. [CrossRef] [PubMed]

99. Gumz, M.L.; Lynch, I.J.; Greenlee, M.M.; Cain, B.D.; Wingo, C.S. The renal $\mathrm{H}^{+}-\mathrm{K}^{+}$-ATPases: Physiology, regulation, and structure. Am. J. Physiol. Renal Physiol. 2010, 298, F12-F21. [CrossRef] [PubMed]

100. Cheval, L.; Morla, L.; Elalouf, J.-M.; Doucet, A. Kidney collecting duct acid-base "regulon". Physiol. Genom. 2006, 27, 271-281. [CrossRef] [PubMed]

101. Silver, R.B.; Mennitt, P.A.; Satlin, L.M. Stimulation of apical H-K-ATPase in intercalated cells of cortical collecting duct with chronic metabolic acidosis. Am. J. Physiol. 1996, 270, F539-F547. [CrossRef] [PubMed]

102. Silver, R.B.; Frindt, G.; Mennitt, P.; Satlin, L.M. Characterization and regulation of H-K-ATPase in intercalated cells of rabbit cortical collecting duct. J. Exp. Zool. 1997, 279, 443-455. [CrossRef]

103. Guh, Y.-J.; Tseng, Y.-C.; Yang, C.-Y.; Hwang, P.-P. Endothelin-1 regulates $\mathrm{H}^{+}$-ATPase-dependent transepithelial $\mathrm{H}^{+}$secretion in zebrafish. Endocrinology 2014, 155, 1728-1737. [CrossRef] [PubMed]

104. Kumai, Y.; Bernier, N.J.; Perry, S.F. Angiotensin-II promotes $\mathrm{Na}^{+}$uptake in larval zebrafish, Danio rerio, in acidic and ion-poor water. J. Endocrinol. 2014, 220, 195-205. [CrossRef] [PubMed]

105. Chou, M.-Y.; Lin, C.-H.; Chao, P.-L.; Hung, J.-C.; Cruz, S.A.; Hwang, P.-P. Stanniocalcin-1 controls ion regulation functions of ion-transporting epithelium other than calcium balance. Int. J. Biol. Sci. 2015, 11, 122-132. [CrossRef] [PubMed]

106. Kumai, Y.; Ward, M.A.R.; Perry, S.F. $\beta$-Adrenergic regulation of $\mathrm{Na}^{+}$uptake by larval zebrafish Danio rerio in acidic and ion-poor environments. Am. J. Physiol. Regul. Integr. Comp. Physiol. 2012, 303, R1031-R1041. [CrossRef] [PubMed]

107. Guh, Y.-J.; Yang, C.-Y.; Liu, S.-T.; Huang, C.-J.; Hwang, P.-P. Oestrogen-related receptor $\alpha$ is required for transepithelial $\mathrm{H}^{+}$secretion in zebrafish. Proc. Biol. Sci. 2016, 283, 20152582. [CrossRef] [PubMed]

108. Brown, J.A.; Edwards, D.; Whitehead, C. Cortisol and thyroid hormone responses to acid stress in the brown trout, Salmo trutta L. J. Fish Biol. 1989, 35, 73-84. [CrossRef]

109. Flik, G.; van der Velden, J.A.; Seegers, H.C.; Kolar, Z.; Wendelaar Bonga, S.E. Prolactin cell activity and sodium fluxes in tilapia (Oreochromis mossambicus) after long-term acclimation to acid water. Gen. Comp. Endocrinol. 1989, 75, 39-45. [CrossRef]

110. Furukawa, F.; Watanabe, S.; Kaneko, T.; Uchida, K. Changes in gene expression levels of somatolactin in the pituitary and morphology of gill mitochondria-rich cells in Mozambique tilapia after transfer to acidic freshwater (pH 3.5). Gen. Comp. Endocrinol. 2010, 166, 549-555. [CrossRef] [PubMed]

111. Kakizawa, S.; Kaneko, T.; Hirano, T. Elevation of plasma somatolactin concentrations during acidosis in rainbow trout (Oncorhynchus mykiss). J. Exp. Biol. 1996, 199, 1043-1051.

112. Briet, M.; Schiffrin, E.L. Aldosterone: Effects on the kidney and cardiovascular system. Nat. Rev. Nephrol. 2010, 6, 261-273. [CrossRef] [PubMed]

113. Wagner, C.A. Effect of Mineralocorticoids on Acid-Base Balance. Nephron Physiol. 2014, 128, 26-34. [CrossRef] [PubMed]

114. Prunet, P.; Sturm, A.; Milla, S. Multiple corticosteroid receptors in fish: From old ideas to new concepts. Gen. Comp. Endocrinol. 2006, 147, 17-23. [CrossRef] [PubMed]

115. Greenwood, A.K.; Butler, P.C.; White, R.B.; DeMarco, U.; Pearce, D.; Fernald, R.D. Multiple Corticosteroid Receptors in a Teleost Fish: Distinct Sequences, Expression Patterns, and Transcriptional Activities. Endocrinology 2003, 144, 4226-4236. [CrossRef] [PubMed]

116. Colombe, L.; Fostier, A.; Bury, N.; Pakdel, F.; Guiguen, Y. A mineralocorticoid-like receptor in the rainbow trout, Oncorhynchus mykiss: Cloning and characterization of its steroid binding domain. Steroids 2000, 65, 319-328. [CrossRef] 
117. Lin, C.-H.; Tsai, I.-L.; Su, C.-H.; Tseng, D.-Y.; Hwang, P.-P. Reverse Effect of Mammalian Hypocalcemic Cortisol in Fish: Cortisol Stimulates $\mathrm{Ca}^{2+}$ Uptake via Glucocorticoid Receptor-Mediated Vitamin D3 Metabolism. PLoS ONE 2011, 6, e23689. [CrossRef] [PubMed]

118. Lin, C.-H.; Hu, H.-J.; Hwang, P.-P. Cortisol regulates sodium homeostasis by stimulating the transcription of sodium-chloride transporter (NCC) in zebrafish (Danio rerio). Mol. Cell. Endocrinol. 2016, 422, 93-102. [CrossRef] [PubMed]

119. Kwong, R.W.M.; Perry, S.F. Cortisol regulates epithelial permeability and sodium losses in zebrafish exposed to acidic water. J. Endocrinol. 2013, 217, 253-264. [CrossRef] [PubMed]

120. Kohan, D.E.; Inscho, E.W.; Wesson, D.; Pollock, D.M. Physiology of endothelin and the kidney. Compr. Physiol. 2011, 1, 883-919. [CrossRef] [PubMed]

121. Licht, C.; Laghmani, K.; Yanagisawa, M.; Preisig, P.A.; Alpern, R.J. An autocrine role for endothelin-1 in the regulation of proximal tubule NHE3. Kidney Int. 2004, 65, 1320-1326. [CrossRef] [PubMed]

122. Laghmani, K.; Preisig, P.A.; Moe, O.W.; Yanagisawa, M.; Alpern, R.J. Endothelin-1/endothelin-B receptormediated increases in NHE3 activity in chronic metabolic acidosis. J. Clin. Investig. 2001, 107, 1563-1569. [CrossRef] [PubMed]

123. Chu, T.S.; Peng, Y.; Cano, A.; Yanagisawa, M.; Alpern, R.J. Endothelin(B) receptor activates NHE-3 by a $\mathrm{Ca}^{2+}$-dependent pathway in OKP cells. J. Clin. Investig. 1996, 97, 1454-1462. [CrossRef] [PubMed]

124. Tsuruoka, S.; Watanabe, S.; Purkerson, J.M.; Fujimura, A.; Schwartz, G.J. Endothelin and nitric oxide mediate adaptation of the cortical collecting duct to metabolic acidosis. Am. J. Physiol. Ren. Physiol. 2006, 291, F866-F873. [CrossRef] [PubMed]

125. Ranhotra, H.S. The orphan estrogen-related receptor $\alpha$ and metabolic regulation: New frontiers. J. Recept. Signal Transduct. 2015, 35, 565-568. [CrossRef] [PubMed]

126. Johns, E.J.; Kopp, U.C.; DiBona, G.F.; Johns, E.J.; Kopp, U.C.; DiBona, G.F. Neural Control of Renal Function. In Comprehensive Physiology; John Wiley \& Sons, Inc.: Hoboken, NJ, USA, 2011; ISBN 9780470650714.

127. Aperia, A.; Ibarra, F.; Svensson, L.B.; Klee, C.; Greengard, P. Calcineurin mediates $\alpha$-adrenergic stimulation of $\mathrm{Na}^{+}, \mathrm{K}^{+}$-ATPase activity in renal tubule cells. Proc. Natl. Acad. Sci. USA 1992, 89, 7394-7397. [CrossRef] [PubMed]

128. Beach, R.E.; Dubose, T.D. Adrenergic regulation of $\left(\mathrm{Na}^{+}, \mathrm{K}^{+}\right)$-ATPase activity in proximal tubules of spontaneously hypertensive rats. Kidney Int. 1990, 38, 402-408. [CrossRef] [PubMed]

129. Liu, F.; Gesek, F.A. $\alpha 1$-Adrenergic receptors activate NHE1 and NHE3 through distinct signaling pathways in epithelial cells. Am. J. Physiol. Ren. Physiol. 2001, 280, F415-F425. [CrossRef] [PubMed]

130. Liu, F.; Nesbitt, T.; Drezner, M.K.; Friedman, P.A.; Gesek, F.A. Proximal nephron $\mathrm{Na}^{+} / \mathrm{H}^{+}$exchange is regulated by $\alpha 1 \mathrm{~A}$ - and $\alpha 1 \mathrm{~B}$-adrenergic receptor subtypes. Mol. Pharmacol. 1997, 52, 1010-1018. [CrossRef] [PubMed]

131. Healy, V.; Thompson, C.; Johns, E.J. The adrenergic regulation of proximal tubular $\mathrm{Na}^{+} / \mathrm{H}^{+}$exchanger 3 in the rat. Acta Physiol. 2014, 210, 678-689. [CrossRef] [PubMed]

132. Hall, R.A.; Premont, R.T.; Chow, C.-W.; Blitzer, J.T.; Pitcher, J.A.; Claing, A.; Stoffel, R.H.; Barak, L.S.; Shenolikar, S.; Weinman, E.J.; et al. The $\beta 2$-adrenergic receptor interacts with the $\mathrm{Na}^{+} / \mathrm{H}^{+}$-exchanger regulatory factor to control $\mathrm{Na}^{+} / \mathrm{H}^{+}$exchange. Nature 1998, 392, 626-630. [CrossRef] [PubMed]

133. Jonz, M.G.; Nurse, C.A. Epithelial mitochondria-rich cells and associated innervation in adult and developing zebrafish. J. Comp. Neurol. 2006, 497, 817-832. [CrossRef] [PubMed]

134. Crowley, S.D.; Coffman, T.M. Recent advances involving the renin-angiotensin system. Exp. Cell Res. 2012, 318, 1049-1056. [CrossRef] [PubMed]

135. Dixit, M.P.; Xu, L.; Xu, H.; Bai, L.; Collins, J.F.; Ghishan, F.K. Effect of angiotensin-II on renal $\mathrm{Na}^{+} / \mathrm{H}^{+}$ exchanger-NHE3 and NHE2. Biochim. Biophys. Acta 2004, 1664, 38-44. [CrossRef] [PubMed]

136. Houillier, P.; Chambrey, R.; Achard, J.M.; Froissart, M.; Poggioli, J.; Paillard, M. Signaling pathways in the biphasic effect of angiotensin II on apical Na/H antiport activity in proximal tubule. Kidney Int. 1996, 50, 1496-1505. [CrossRef] [PubMed]

137. Schuster, V.L.; Kokko, J.P.; Jacobson, H.R. Angiotensin II directly stimulates sodium transport in rabbit proximal convoluted tubules. J. Clin. Investig. 1984, 73, 507-515. [CrossRef] [PubMed]

138. Pech, V.; Zheng, W.; Pham, T.D.; Verlander, J.W.; Wall, S.M. Angiotensin II Activates $\mathrm{H}^{+}$-ATPase in Type A Intercalated Cells. J. Am. Soc. Nephrol. 2008, 19, 84-91. [CrossRef] [PubMed] 
139. Talati, G.; Ohta, A.; Rai, T.; Sohara, E.; Naito, S.; Vandewalle, A.; Sasaki, S.; Uchida, S. Effect of angiotensin II on the WNK-OSR1/SPAK-NCC phosphorylation cascade in cultured mpkDCT cells and in vivo mouse kidney. Biochem. Biophys. Res. Commun. 2010, 393, 844-848. [CrossRef] [PubMed]

140. San-Cristobal, P.; Pacheco-Alvarez, D.; Richardson, C.; Ring, A.M.; Vazquez, N.; Rafiqi, F.H.; Chari, D.; Kahle, K.T.; Leng, Q.; Bobadilla, N.A.; et al. Angiotensin II signaling increases activity of the renal Na-Cl cotransporter through a WNK4-SPAK-dependent pathway. Proc. Natl. Acad. Sci. USA 2009, 106, 4384-4389. [CrossRef] [PubMed]

141. Ko, B.; Mistry, A.; Hanson, L.; Mallick, R.; Hoover, R.S. Mechanisms of angiotensin II stimulation of NCC are time-dependent in mDCT15 cells. Am. J. Physiol. Ren. Physiol. 2015, 308, F720-F727. [CrossRef] [PubMed]

142. Sazonova, O.; James, K.A.; McCudden, C.R.; Segal, D.; Talebian, A.; Wagner, G.F. Stanniocalcin-1 secretion and receptor regulation in kidney cells. Am. J. Physiol. Ren. Physiol. 2008, 294, F788-F794. [CrossRef] [PubMed]

143. Madsen, K.L.; Tavernini, M.M.; Yachimec, C.; Mendrick, D.L.; Alfonso, P.J.; Buergin, M.; Olsen, H.S.; Antonaccio, M.J.; Thomson, A.B.; Fedorak, R.N. Stanniocalcin: A novel protein regulating calcium and phosphate transport across mammalian intestine. Am. J. Physiol. 1998, 274, G96-G102. [CrossRef] [PubMed]

144. Tseng, D.-Y.; Chou, M.-Y.; Tseng, Y.-C.; Hsiao, C.-D.; Huang, C.-J.; Kaneko, T.; Hwang, P.-P. Effects of stanniocalcin 1 on calcium uptake in zebrafish (Danio rerio) embryo. Am. J. Physiol. Regul. Integr. Comp. Physiol. 2008, 296, R549-R557. [CrossRef] [PubMed]

(C) 2018 by the authors. Licensee MDPI, Basel, Switzerland. This article is an open access article distributed under the terms and conditions of the Creative Commons Attribution (CC BY) license (http:/ / creativecommons.org/licenses/by/4.0/). 